identity unmistakable. On the whole it seems best that a species of such questionable validity should be dropped.

To the list of California willows, as known ten years ago, not a single addition has been made, though it is highly probable that S. rostrata, S. vestita and S. reticulata will be found in the Sierra Nevada; and S. Hookeriana (known to occur abundantly along the coast of Oregon down almost to the boundary line) may be confidently looked for at the mouth of the Klamath river.

Rockford, Ills.

\title{
Notes on the flora of the St. Croix region.
}

\author{
E. G. HILL.
}

The Dalles of the St. Croix and the neighboring rapids are a piece of scenery very attractive to one seeking the beautiful and picturesque in nature. They are formed by a belt of trappean rocks of the copper-bearing series which crosses the river in this region, making several ridges from 200 to 300 feet high. Softer sandstones of the Potsdam or Cambrian formation, mingled with conglomerates and shales at the points of contact, are laid down upon the trap in horizontal strata, or abut against the sides of its uplifted beds, clearly showing their unconformability. Through these rocks the river has worn a deep gorge, and by a series of rapids and low falls rushes along between bluffs descending rather steeply as wooded slopes. On the Minnesota side of the stream the bluffs recede from its banks far enough to leave a nearly level spot on which stands the lower part of the village of Taylor's Falls. On the opposite slope, in the state of Wisconsin, lies the village of St. Croix Falls. In the midst of the rapids the river is spanned by a bridge at a point where it becomes quite narrow at the head of a defile, making it easy to cross to either side. For some distance below the bridge the water rushes on over the sloping rocks in impetuous swirls, then makes a sudden bend and glides on with comparative placidity between cliffs from 100 to 200 feet high. The walls of these cliffs are either vertical or nearly so. The Dalles are properly that portion of the gorge beginning at the bridge, and furnish much the most imposing part of the scenery. It con- 
tinues for several miles, but the rocks, composed of softer or less elevated materials have been worn away to a greater width, and the bluffs and cliffs again recede from the river, leaving a strip of flats along its banks. About two miles below Taylor's Falls another cañon is formed, called the Lower Dalles, but it lacks the wild rapids connected with the Upper Dalles.

To clamber over the rough rocks, to climb the steep ridges and the cliffs where practicable, to gather plants whose home is in such haunts, while enjoying the enchanting views, is delightful though wearisome work. One is also reminded that he is on ground somewhat classical for the botany of the upper Mississippi, since he is collecting in the footsteps of men who have honored names as pioneers in botanical exploration. Here Dr. Douglas Houghton collected plants in 1832, acting as surgeon and botanist to the expedition of Schoolcraft to the source of the Mississippi river. On its way home it explored the St. Croix, passing up this stream and crossing the narrow divide that separates it from the Brulé or Burntwood river, down which the party passed to Lake Superior. Some of the plants secured in this and the preceding expedition of 1831 are listed in the appendix to the narrative of the expedition to Itaska lake, and are credited to the St. Croix river. The late Dr. C. C. Parry, one of the members of Owen's Geological Survey, whose work included this region, collected here in 1848 , and several of the plants given in the catalogue as a part of the report are from the St. Croix river, the Falls of the St. Croix taking their full share.

The time of visiting the Dalles was opportune in another respect, as it coincided with the occurrence of a log-jam for which this part of the St. Croix is noted. This had a botanical side, and furnished matters for reflection to one at all interested in the problem of forestry. To see the millions of feet of logs piled several deep in the river, and bridging it over a mile of its length, gave one a vivid idea of the rate of destruction at which the forests of pine along the upper St. Croix and its tributaries must be going on, in order to supply this material. And when this mass was added to the logs of numerous streams carrying their burdens to the Mississippi and the Great Lakes, and to the quantities of lumber transported by cars and water-craft, one could but ask in despair how long this can continue before the last stick is taken. 
The forcing of the logs from their chaotic tangle by the skillful raftsmen looked like a perilous undertaking, but all passed off without serious accident. Many excursionists came from surrounding parts to see the jam, and watched the workmen with deep interest. The excitement of a spectator was at its height when a large section of the raft began to move, and the lumbermen hurried ashore to escape from the rush of logs coming down with resistless weight. There were heavy sounds of rubbing, and grinding and crushing, and if one of the smaller logs became fast in the rocks, or was caught and turned on end, it was quickly snapped in two. Again the huge raft crowded down from above and filled the space in the gorge vacated by the outgoing timbers, only to stop once more as it reached the sharp bend at the foot of the rapids, and the logs were wedged in between the cliffs. This operation was repeated several times, till the defile was cleared and the logs above ceased to come down in quantities sufficient to fill it. These were then loosened by degrees, and sent down in a safe number till the stream was cleared of obstructions after a work of a fortnight. As a witness of the jam and of the thousands of logs which, so to speak, passed in review, a deep impression was made upon my mind other than those due to its novel and exciting features. It represented a great waste of material from the point of view of true forestry and of the real lumber interests of the country. Multitudes of the logs cut for the mills were little more than poles, and far too many besides cut from trees too small and immature for the profit which a wise regard for the future would dictate. True it is claimed by lumbermen that it is best to cut all the merchantable trees from a tract they may be cutting over, because all that are left become a prey to fires rendered much more frequent and destructive by the dry remnants of trees. This may be a valid excuse under existing regulations; but it proves still more clearly the need of adequate forest management either by state or national government to check the waste from any cause.

There are features of more than usual botanical and geological interest to one working among the rocks of the St. Croix. The mass of the rocks is greenish, or grayish-green, and granular, porphyritic, or amygdaloidal in structure. Being unaware of the nature of the outcrop at the time of visiting the Dalles, their identity with those on the Keweenaw 
Peninsula was at once recognized. Hand specimens of the two could hardly be distinguished from one another. They are such as bear the general designation of melaphyr, the diabase-porphyry of Irving. ${ }^{1}$ It is evident to those studying the relations of plants and soil, that the materials arising from the decomposition of such rocks will to some extent affect the flora. The shaded cliffs, and crevices by which they are seamed and broken in many ways also afford a congenial home for numerous ferns. They were not only in great abundance, but also of fine development. They may be called the most characteristic features of the flora of the Dalles.

The most interesting fern I met with was Aspidium fragrans Swartz. Some fronds were nearly a foot long, exclu sive of the chaffy stipe. Its pale or ashy color, its glandular pinnae, its balsamic fragrance, at once show that a fern quite different from the common kinds is in hand. It grows in the clefts of the rocks, preferring the shaded, vertical fissures, clinging to them where a foothold can be obtained. Dr. Parry first detected it here within the limits of the United States. He remarks of it in his Catalogue: "I am informed by Dr. Torrey that this species has never before been found in the United States, but has been obtained in British America and Kamtschatka. In the locality here specified it is quite abundant."2 It is still abundant, at least on the Wisconsin side of the river, where most of the ferns collected were obtained. Since Parry's discovery of it here it has been found in several localities from northern New England westward, keeping well towards the British Provinces.

Woodsia obtusa Torr., is seen in similar situations, but is not so abundant. Woodsia Ilvensis R. Br., is one of the most frequent of the rock ferns, growing on their exposed faces in all localities. Wherever I have found it, and this has been in many localities from the Saguenay westward in the region of the St. Lawrence and the Great Lakes, it shows itself a plant capable of enduring the severest drouths. The fronds often look crisp and apparently dead, but quickly revive when moistened.

The delicate Cystopteris fragilis Bernh. was obtained from the shaded cliffs, and on the Minnesota side a few specimens more like the var. dentata Hooker were taken from similar

${ }^{1}$ The Copper-bearing Rocks of Lake Superior, by R. D. Irving.

2Owen's Report, p. 621 . 
places. Once I came across Camptosorus rhizophyllus Link. It covered a space of a few square feet on some detached rocks in a deep shady nook beside a pond. This may be where Parry found it, since he gives as its habitat. — "Shaded and detached rocks, Falls of St. Croix." It was my first sight of this fern in the West, though I have often looked for it in favorable localities. The rocks on which it grew were trappean. It is generally, but not exclusively, credited to calarceous rocks. The only place besides this where I have seen it was in Western New York, where it grew in shaded places along the shelves of cliffs of limestone. In that pleasant little book of Williamson, "Ferns of Kentucky," he says of it, "It is found in all our Kentucky woo ts wherever there are detached mosscovered boulders, on outcropping rocks and cliffs either limestone or sandstone."

Another rare or local plant was gathered from the rocks above the village of Taylor's Falls, Talinum teretifolium Pursh. Houghton found it here in 1832. It is occasionally met with from Pennsylvania westward to Minnesota in our northern flora, being more common in Minnesota than elsewhere in this range of states. The Manual accords it as a habitat, "serpentine rocks," a much too restricted one. They are not of that character here, being diabase, though chemically, if this be needful, some of the same elements and their compounds could be yielded on decomposition. Upham, in the Minnesota Catalogue, says of the plant, "Rare, occurring only on ledges of rock, (trap, syenite, granite and quartzite).' I have found it but once before, in the silicious sands at Miller's, Lake Co., Ind. In Illinois it is found in "sandy prairies and barrens," as stated in Patterson's "Catalogue of the Plants of Illinois." At Taylor's Falls three other plants accompanied it on the trappean rocks, which are also found with it at Miller's, Campanula rotundifolia, Selaginella rupestris, and Cladonia rangiferina. All these do well in the sand. It shows that the Talinum would be easy to cultivate. Its flowers are pretty, though expanding late in the day and lasting but a short time; but its cylindrical leaves give it an odd though interesting look. It does not rival in the abundance of its flowers its congener from Central America, Talimum patens Willd., cultivated for platbands and as a basket plant, but would excel it in being hardy in our latitude, and might be used in a similar way, as well as for rockwork. As Vilmorin 
says of T. patens, "It keeps fresh in spite of heat and drouth, and will grow vigorously on unshaded rocks.", 1

Not uncommon on the rocks were specimens of Houstonia purpurea L. var. longifolia Gray. The characteristics were intermediate, allying it more closely to the type than ordinary examples of the variety; the leaves being sometimes threeribbed and somewhat tufted or rosulate near the root. Several stems usually grow from the same root. The only plants besides calling for notice are, Oxybaphus nyctagineus, seen occasionally on the rocky banks, and Gentiana alba in springy ground.

Englewood, Chicago.

(Concluded next month.)

\section{BRIEFER ARTICLES.}

A new Aster from California (with plate XI).-Aster Orcuttii Vasey \& Rose, n. sp.- Stems suffruticose, somewhat branching, pearly white, glabrous: lower leaves obovate, I to 2 in. long, with cuneate base; upper ones often oblong, with broad sessile or somewhat clasping base, obtuse at tip, spinulose-toothed, glabrous: heads solitary and terminal on leafy branches, sessile or nearly so, very large, an inch or more in diameter: bracts of the involucre closely imbricated in 3 or 4 series, oblong with tapering green tips ciliate on the margins: rays an inch long, "lavender to delicate mauve color": disk-flowers 4 lines long, tapering toward the base: style branches broad: achenes densely long white villous: pappus coarse and scabrous.-Collected at "Cariso Creek Wash," Colorado Desert, California (where it is very abundant), April and November, by $C$. R. Orcutt.-This handsome flowered species, although it resembles in habit and leaf some species of Aplopappus, evidently belongs to Gray's section Megalastrum under Aster, and near A. tortifollus. It differs from that species in its almost sessile head, different involucral bracts, obtuse leaves, and larger diskflowers. Mr. Orcutt obtained seeds of it and considers it worthy of cultivation.- J. N. Rose, Department of Agriculture, Washington, D. C.

A new Fomes from northern Montana. (With plate XII).-Fomes Ellisianus Anders., n. sp.:-On the living trunks and larger branches of Shepherdia argentea, valley of the Teton, opposite the "Three Knees," buttes of the Marias river, northern Montana, July r889. Anderson, no. 537 .

\footnotetext{
${ }^{1}$ Les Fleurs de pleine Terre, p. 1124.
} 


\section{$2 \mathrm{BHL}$ Biodiversity Heritage Library}

Hill, E J . 1891. "Notes on the Flora of the St. Croix Region." Botanical gazette 16(4), 108-113. https://doi.org/10.1086/326639.

View This Item Online: $\underline{\text { https://www.biodiversitylibrary.org/item/38663 }}$

DOI: https://doi.org/10.1086/326639

Permalink: https://www.biodiversitylibrary.org/partpdf/222031

\section{Holding Institution}

Missouri Botanical Garden, Peter H. Raven Library

\section{Sponsored by}

Missouri Botanical Garden

\section{Copyright \& Reuse}

Copyright Status: Public domain. The BHL considers that this work is no longer under copyright protection.

This document was created from content at the Biodiversity Heritage Library, the world's largest open access digital library for biodiversity literature and archives. Visit BHL at https://www.biodiversitylibrary.org. 